\title{
ANAUSIS KANDUNGAN BORAKS DAN FORMALN PADA BEBERAPA PEDAGANG BAKSO DI KOTA MATARAM
}

\author{
Adi Saputrayadi ${ }^{*}$, Asmawati $^{2}$, Marianah ${ }^{2}$, Suwati2 \\ ${ }^{1}$ Teknologi Hasil Pertanian, Universitas Muhammadiyah Mataram, adhigondris@gmail.com \\ ${ }^{2}$ Teknologi Hasil Pertanian, Universitas Muhammadiyah Mataram
}

\section{INFO ARTIKEI}

RiwayatArtikel:

Diterima: 24- 03-2018

Disetujui: 27-06-2018

\section{Kata Kunci:}

Bakso

Pedagang Bakso

Formalin

Boraks

\begin{abstract}
ABSTRAK
Penelitian ini bertujuan ingin mengetahui apakah terdapat kandungan boraks dan formalin pada bakso yang dijual oleh pedagang yang memiliki warung bakso permanen di Kota Mataram melalui uji di Laboratorium Universitas Muhammadiyah Mataram. Hasil penelitian dapat menggambarkan penggunaan bahan tambahan pangan berbahaya oleh pedagang bakso yang ada di kota mataram. Lokasi pengambilan sampel penelitian adalah beberapa tempat pedagang bakso di Kota Mataram dengan kriteria pedagang bakso yang menetap bukan pedagang kaki lima dan bukan pedagang keliling. Metode penelitian ini adalah metode eksprimental dengan melakukan uji di laboratorium. Tahapan penelitian terdiri dari: (1) proses pengumpulan sampel dari 12 pedagang bakso di kota mataram, masing-masing kecamatan diwakili 2 pedagang bakso, (2) Uji kandungan boraks dan formalin, (3) analisis sifat organoleptik bakso. Berdasarkan hasil analisis, dari 12 sampel yang dikumpulkan menunjukkan bahwa tidak ada yang mengandung boraks (0\%), tetapi $100 \%$ mengandung formalin. Keberadaan formalin pada bakso tidak mempengaruhi sifat kadar air bakso. Pada penilaian terhadap sifat organoleptik bakso terhadap parameter aroma dan rasa menunjukkan bahwa keberadaan formalin tidak memberikan pengaruh nyata, sedangkan untuk parameter warna sampel dengan skor nilai warna terendah pada perlakuan B2 yaitu 1.87 dengan penggunaan formalin pada bakso tersebut sangat tinggi, sedangkan skor nilai warna tertinggi pada perlakuan B3 yaitu 3.67 dengan penggunaan formalin agak sedikit, sehingga dapat diketahui bahwa keberadaan formalin pada pedagang bakso diwilayah kota Mataram berpengaruh terhadap warna bakso. Parameter tekstur sampel dengan skor nilai tekstur terendah pada perlakuan B2 yaitu 2.00 dengan penggunaan formalin sangat tinggi, sedangkan skor nilai tekstur tertinggi pada perlakuan B11 yaitu 3.47 dengan penggunaan formalin agak sedikit. Sehingga dapat diketahui bahwa keberadaan formalin pada pedagang bakso diwilayah kota mataram berpengaruh terhadap tekstur bakso.
\end{abstract}

\begin{abstract}
This study aims to find out whether there are borax and formalin contents in meatballs sold by traders who have permanent meatball stalls in Mataram City through tests at the Laboratory of Muhammadiyah University Mataram. The results of the study can illustrate the use of hazardous food additives by meatball traders in the city of Mataram. The location of the research sample is several places of meatball traders in the city of Mataram with the criteria of meatball traders who live not street vendors and not mobile traders. The method used in this study is an experimental method by testing in the laboratory. The stages of this study consisted of: (1) the process of collecting samples from 12 meatball traders in Mataram city, each sub-district was represented by 2 meatball traders, (2) the test of borax and formalin content, (3) the analysis of organoleptic properties of meatballs. Based on the results of the analysis, of the 12 samples collected showed that none contained borax (0\%), but 100\% contained formaldehyde. The presence of formalin in meatballs does not affect the nature of the meatball water content. In the assessment of organoleptic properties of meatballs on aroma and flavor parameters showed that the presence of formaldehyde did not give a significant effect, while for the color parameters of the sample with the lowest color value score on treatment B2 that is 1.87 with the use of formalin in the meatball was very high, while the highest color value B3 treatment is 3.67 with a little use of formalin, so it can be seen that the presence of formaldehyde in meatball traders in the city area of Mataram affects the color of meatballs. Sample texture parameters with the lowest texture value score on B2 treatment were 2.00 with very high use of formalin, while the highest texture value score in B11 treatment was 3.47 with a little formalin use. So that it can be seen that the presence of formalin in meatball traders in the city area of Mataram influences the texture of meatballs.
\end{abstract}

\section{A. LATAR BELAKANG}

Dalam Islam masalah halal haram adalah prinsip. Setiap muslim terikat dengan ketentuan halal haram dalam setiap aktivitasnya. Termasuk penggunaan bahan-bahan untuk keperluan konsumsi seperti makanan dan minuman, sehingga wajib baginya 
mempertimbangkan aspek kehalalan ketika hendak menggunakan barang-barang untuk dikonsumsi. Setiap muslim juga berkewajiban untuk menghindarai produk-produk subhat, yaitu produk yang tidak jelas kehalalannya.

Doktrin yang mengharuskan untuk memilih konsumsi yang halal dijelaskan dalam banyak ayat AlQur'an dan Hadits. Dalam Al-Qur'an antara lain Allah SWT telah berfirman yang artinya : " Hai sekalian manusia, makanlah yang halal lagi baik dari apa yang terdapat di bumi, dan janganlah kamu mengikuti langkah-langkah syaitan, karena sesungguhnya syaitan itu adalah musuh yang nyata bagimu. “( QS. Al-Baqarah : 168 ).

Dalam hadits Nabi, diantaranya Rasulullah SAW bersabda: " Dari Anas bin Malik Ra, dari Nabi SAW beliau bersabda : " mencari yang halal adalah wajib bagi setiap orang Islam. " ( HR al-Thabrani ).

Pada prinsipnya, semua bahan makanan dan minuman adalah halal kecuali yang telah dinyatakan keharamannya oleh Allah Sut dan Rasul-Nya. Antara lain yang telah disebutkan dalam Al-Qur'an : bangkai, darah, babi dan hewan yang disembelih atas nama selain Allah Sut, kemudian hal-hal yang yang menjijikkan atau kotor ( al-khaba'its ). Beberapa jenis makanan yang berasal dari sumber binatang seperti daging dan bagian lainnya, agar halal dikonsumsi harus disembelih dahulu dengan cara mengikuti syariat islam. Di luar hal tersebut, setiap orang tidak boleh sembarangan mengatakan halal haram tanpa ada dasar yang benar dan bisa dipertanggungjawabkan.

Doktrin ini juga bersumber dari Al-Qur'an dan Hadits, antara lain dalam surat An-Nahl : 116, Allah Sut berfirman yang artinya : " Dan janganlah kamu mengatakan terhadap apa yang disebut-sebut oleh lidahmu secara dusta " ini halal dan ini haram ", untuk mengada-adakan kebohongan terhadap Allah. Sesungguhnya orang-orang yang mengada-adakan kebohongan terhadap Allah tiadalah beruntung ". Kemudian dalam Hadits, Rasulullah Saw bersabda : " Halal adalah segala sesuatu yang Allah halalkan dalam kitab-Nya, sedangkan haram adalah segala sesuatu yang Allah haramkan dalam kitab-Nya. Adapaun yang Allah diamkan maka itu yang Dia memaafkannya. " ( HR. Al Tirmiidzi, Abu Dawud dan Ibnu Majah ).

Fenomena global telah memunculkan masalah baru yaitu : (a) beredarnya berbagai produk pangan, mulai dari bahan baku sampai dengan produk jadi yang berasal dari berbagai penjuru dunia, tanpa bisa dibatasi. Termasuk yang diproduksi di daerah atau negara non-muslim. (b) Produk-produk daging yang berasal dari sembelihan non-muslim pun masuk ke pasar bebas dalam bentuk daging mentah dan produk daging olahan seperti sosis, bakso, nugget dan sebagainya. Bahkan ada yang sudah menjadi produk 108 turunan daging dan lemak, yang kesemuanya susah untuk diidentifikasi asal-usulnya. (c) Terdapat kasus penyimpangan yang disengaja, seperti mencampur daging sapi dengan daging babi untuk dendeng dan bakso. Juga kasus produsen bakso yang mencampur daging babi dengan daging sapi, mencampur produk bakso dengan bahan pengawet boraks dan formalin sehingga memunculkan produk yang ada unsur haramnya. Sementara tidak semua orang islam mampu mengidentifikasi. Dengan demikian muncul keraguan bagi konsumen terhadap produk-produk tersebut.

Makanan halal akan mencakup hal yang jelas pelarangannya melalui nash-nash agama, misalnya islam melarang makan babi, darah atau sembelihan yang tidak menyebut nama Allah, juga berkaitan dengan eksistensi kesehatan manusia. Dari poin diatas menunjukkan persoalan produk halal tidak saja berkaitan dengan kebutuhan mengikuti syariah tapi juga berkaitan dengan higienitas, sanitasi dan juga keamanan ( Baharuddin, et al, 2015 ).

Salah satu yang membuat geger masyarakat barubaru ini adalah penemuan kandungan formalin dan Boraks pada sejumlah produk makanan, dan sebagian besar pada jenis mi, tahu, bakso dan juga ikan asin, yang selama ini banyak dikonsumsi masyarakat luas. Formalin adalah zat kimia yang mengandung unsur karbon, hidrogen, dan oksigen, dan mempunyai nama lain formaldehid. Secara fisik terdapat dalam bentuk larutan tidak berwarna dengan kadar antara 37-40\%. Formalin biasanya mengandung alkohol/metanol 10$15 \%$ yang berfungsi sebagai stabilisator untuk mencegah polimerisasi formaldehid menjadi paraformaldehid yang bersifat sangat beracun. Karakteristik dari zat ini adalah mudah larut dalam air, mudah menguap, mempunyai bau yang tajam dan iritatif walaupun ambang penguapannya hanya $1 \%$, mudah terbakar bila kontak dengan udara panas atau api, atau bila kontak dengan zat kimia tertentu. Di pasaran tersedia dalam bentuk sudah diencerkan maupun dalam bentuk padat.

Berdasarkan data yang dihimpun oleh BPOM pada tahun 2005 bahwa bahan makanan yang menduduki peringkat teratas mengandung formalin dan boraks adalah ikan laut, mie basah, tahu dan bakso. Hasil penelitian BPOM yang dimulai pada minggu keempat November 2009 sampai akhir januari 2010 untuk mengetahui makanan yang paling banyak mengandung boraks dan formalin dengan uji sampling terhadap jajanan anak sekolah dienam ibu kota propinsi di Pulau J awa, seperti Jakarta, Serang, Bandung, Semarang, Yogyakarta, dan Surabaya antara lain 30 SD di Jakarta, 31 SD di Serang, 26 SD di Bandung, 10 SD di Semarang, 24 SD di Yogyakarta, dan 33 SD di Surabaya, sekitar lima jenis jajanan mengandung bahan kimia berbahaya. Kelima jajan itu berupa sirup, saus, kerupuk, bakso, dan mie. 
Kandungan berbahaya diantaranya kerupuk gendar yang mengandung rhodamin $B$, saus yang mengandung methanil yellow, bakso mengandung boraks, dan mie yang mengandung formalin (Fardiaz, 2007).

Bakso adalah jenis makanan yang berupa bola-bola yang terbuat dari daging dan tepung. Makanan ini biasanya disajikan dengan kuah dan mie. Bahanbahan yang dibutuhkan dalam pembuatan bakso adalah daging, bahan perekat, bumbu dan es batu/ air es (Singgih, 2009). Biasanya jenis bakso di masyarakat pada umumnya diikuti dengan nama jenis bahan seperti bakso ayam, bakso ikan dan bakso sapi atau bakso daging. Bakso merupakan salah satu olahan daging secara tradisional, yang sangat terkenal dan digemari oleh semua lapisan masyarakat, karena memiliki rasa yang khas, enak, dan kaya gizi. Bakso memiliki kandungan protein dan kadar air tinggi serta $\mathrm{pH}$ netral, sehingga rentan terhadap kerusakan dan daya awet maksimal 1 hari pada suhu kamar. Bahan baku bakso dapat berasal dari berbagai daging jenis ternak, seperti: sapi, ayam dan ikan (Purnomo, 1998).

Daging adalah jaringan otot dari hewan yang berbentuk serat-serat otot yang panjang dan tipis yang diikat menjadi satu oleh lapisan tipis dari jaringan ikat yang menyambung antara satu dengan yang lain. Daging merupakan bahan pangan sumber protein berkualitas tinggi karena mengandung asam amino esensial, juga sebagai sumber vitamin B kompleks dan kandungan vitamin-vitamin yang larut dalam lemak yaitu vitamin A, D, E, K. Dalam Setiap 100 gram daging sapi mengandung kalori $207 \mathrm{Kkal}$, protein 18,8 gram, lemak 14 gram, kalsium $11 \mathrm{mg}$, besi 2,8 mg dan vit A $30 \mathrm{mg}$ dan Vit B 0,08 mg (DKBM, 2005). Bahan baku bakso dimasyarakat selama ini menggunakan daging sapi.

Penggunaan bahan baku daging sapi memiliki harga produksi yang lebih mahal. Hal ini menjadi dilema bagi masyarakat yang ingin memenuhi kebutuhan protein dari daging sapi. Disisi lain ada penyakit yang mengancam seperti: hiperkolesterol, jantung dan kanker. Pada umumnya dalam pengelolaan makanan selalu diusahakan untuk menghasilkan produk makanan yang disukai dan berkualitas baik. Makanan yang tersaji harus tersedia dalam bentuk dan aroma yang lebih menarik, rasa enak, warna dan konsistensinya baik serta awet.

Untuk mendapatkan makanan seperti yang diinginkan maka sering pada proses pembuatannya dilakukan penambahan "Bahan Tambahan Pangan (BTP)" yang disebut zat aktif kimia (food additive) (Widyaningsih, 2006). BTP ditambahkan untuk memperbaiki karakter pangan agar memiliki kualitas yang meningkat. BTP pada umumnya merupakan bahan kimia yang telah diteliti dan diuji sesuai dengan kaidah-kaidah ilmiah yang ada.
Pemerintah sendiri telah mengeluarkan berbagai aturan yang diperlukan untuk mengatur pemakaian BTP secara optimal (Syah, 2005). Adapun bahan kimia berbahaya yang bukan ditujukan untuk makanan, justru ditambahkan kedalam makanan adalah formalin, boraks, rhodamin B dan methanil yellow. Diantara beberapa jenis bahan kimia berbahaya tersebut yang paling sering digunakan secara bebas di masyarakat adalah formalin dan boraks.

Meskipun sebagian banyak orang sudah mengetahui terutama produsen makanan bahwa zat ini berbahaya jika digunakan sebagai pengawet, namun penggunaannya bukannya menurun namun malah semakin meningkat dengan alasan harganya yang relatif murah dibandingkan dengan pengawet yang tidak dilarang. Formalin merupakan salah satu bahan kimia yang dilarang oleh pemerintah. Pemakaian formalin oleh pedagang sebagai bahan pengawet makanan dapat disebabkan karena kurangnya informasi tentang bahaya pemakaian formalin, tingkat kesadaran kesehatan masyarakat yang masih rendah, harga formalin yang sangat murah dan lebih mudah untuk diperoleh serta efektif digunakan sebagai pengawet walaupun hanya dalam jumlah sedikit (Saparinto dan Hidayati, 2006 dalam Sari, 2014).

Penelitian ini dilakukan untuk mengetahui tingkat penggunaan boraks dan formalin pada mie dan bakso di beberapa tempat penjual bakso di Kota Mataram. Perkembangan pariwisata mendorong banyak tumbuhnya warung bakso di Kota Mataram sehingga perlu dilakukan penelitian di beberapa tempat penjual bakso yang diduga produk mie dan bakso yang digunakan mengandung boraks dan formalin.

\section{B. METODE PENELITIAN}

\section{Metode, Tempat, dan Waktu}

Metode yang digunakan dalam penelitian ini adalah metode eksperimental dengan percobaan di Laboratorium. Penelitian dilaksanakan pada bulan Mei hingga Agustus 2018. Lokasi pengambilan sampel adalah beberapa tempat pedagang bakso di Kota Mataram dengan kriteria pedagang bakso yang menetap bukan pedagang kaki lima dan bukan pedagang keliling. Analisis kimia dan organoleptik dilakukan di Laboratorium Pengolahan Fakultas Pertanian Universitas Muhammadiyah Mataram.

\section{Bahan dan Alat}

Bahan yang digunakan dalam penelitian ini adalah sampel bakso dari 12 pedagang bakso di kota mataram, reagen test kit boraks dan formalin easy tes (Fitri A.L. dkk. 2014). Alat yang digunakan dalam 
penelitian ini adalah cawan porselin, mortir, sendok, batang pengaduk, beaker glass $25 \mathrm{ml}$, neraca teknis.

\section{Tahapan Penelitian}

Penelitian ini bertujuan ingin mengetahui apakah terdapat kandungan boraks dan formalin pada bakso yang dijual oleh pedagang yang memiliki warung bakso permanen di Kota Mataram melalui uji di Laboratorium Universitas Muhammadiyah Mataram. Hasil penelitian dapat menggambarkan penggunaan bahan tambahan pangan berbahaya oleh pedagang bakso yang ada di kota mataram. Lokasi pengambilan sampel penelitian adalah beberapa tempat pedagang bakso di Kota Mataram dengan kriteria pedagang bakso yang menetap bukan pedagang kaki lima dan bukan pedagang keliling. Setiap Perlakuan dilakukan dengan 3 kali ulangan. Pendenahan dalam rancangan percobaan ini dapat dilihat pada Tabel 1. Penelitian ini dilaksanakan dalam beberapa tahapan, diantaranya adalah tahap pengumpulan sampel dan melakukan analisi di laboratorium . Adapun tahapan sebagai berikut :

Terlebih duhulu membeli sampel bakso yang dijual oleh pedagang yang memiliki warung bakso permanen di Kota Mataram. Lokasi pengambilan sampel penelitian adalah beberapa tempat pedagang bakso di Kota Mataram dengan kriteria pedagang bakso yang menetap bukan pedagang kaki lima dan bukan pedagang keliling. Prosedur Pengambilan Sampel : a. Bakso diambil dari 12 pedagang bakso di 6 kecamatan di kota Mataram, b. dimasukkan dalam kantong plastik, c. dibawa ke laboratorium Universitas Muhammadiyah Mataram. Prosedur Uji Boraks Dan Formalin : a. Ambil 5 gr mie basah dan bakso yang akan diamati. b. Lumatkan mie basah dan bakso tersebut pada cawan porselin. c. Dimasukkan ke dalam beaker glass $25 \mathrm{ml}$. d. Tambahkan reagen test kit boraks dan formalin easy tes sebanyak 4 tetes. e. Tambahkan air mendidih $5 \mathrm{ml}$, aduk sampai padatan mie basah dan bakso dapat bercampur rata dengan cairan sampai menyerupai bubur. f. Biarkan dingin, lalu ambil kertas uji dan celupkan kertas uji dengan campuran tersebut, jika kertas uji yang semula berwarna kuning berubah menjadi merah bata maka mie basah dan bakso tersebut positif mengandung boraks dan jika warna kertas uji tetap maka mie basah dan bakso tersebut negatif kadungan boraks atau formalinnya (Fitri A.L. dkk. 2014).

Rancangan yang digunakan adalah rancangan acak lengkap (RAL) dengan satu faktor yaitu bakso yang mengandung boraks dan formalin pada penjual bakso di kota mataram.

\section{Pengolahan dan Analisis Data}

Data yang diperoleh dari hasil uji laboratorium diolah dan dimasukkan kedalam tabel kemudian didiskripsikan.

Tabel 1.

Hasil Uji Boraks Terhadap Sampel Bakso

\begin{tabular}{|c|c|c|c|c|c|c|}
\hline \multicolumn{3}{|c|}{ Kota Mataram } & \multicolumn{4}{|c|}{ Boraks } \\
\hline \multirow{2}{*}{ No } & \multirow{2}{*}{ Kecamatan } & \multirow{2}{*}{ Bakso } & \multicolumn{3}{|c|}{ Ulangan } & \multirow[t]{2}{*}{ ket } \\
\hline & & & 1 & 2 & 3 & \\
\hline \multirow{2}{*}{1.} & \multirow{2}{*}{ Ampenan } & 1. Bakso 1 & & & & \\
\hline & & 2. Bakso 2 & & & & \\
\hline \multirow{2}{*}{2.} & \multirow{2}{*}{ Cakranegara } & 3. Bakso 3 & & & & \\
\hline & & 4. Bakso 4 & & & & \\
\hline \multirow{2}{*}{3.} & \multirow{2}{*}{ Mataram } & 5. Bakso 5 & & & & \\
\hline & & \begin{tabular}{|l|l|}
6. & Bakso 6 \\
\end{tabular} & & & & \\
\hline \multirow{2}{*}{4.} & \multirow[b]{2}{*}{ Sekarbela } & 7. Bakso 7 & & & & \\
\hline & & 8. Bakso 8 & & & & \\
\hline \multirow{2}{*}{5.} & \multirow{2}{*}{ Sandubaya } & 9. Bakso 9 & & & & \\
\hline & & 10. Bakso 10 & & & & \\
\hline \multirow{2}{*}{6.} & Selaparang & 11. Bakso 11 & & & & \\
\hline & \multicolumn{2}{|c|}{ Kota Mataram } & \multicolumn{4}{|c|}{ Formalin } \\
\hline \multirow{2}{*}{ No } & \multirow{2}{*}{ Kecamatan } & \multirow[b]{2}{*}{ Bakso } & \multicolumn{3}{|c|}{ Ulangan } & ket \\
\hline & & & 1 & 2 & 3 & \\
\hline \multirow{2}{*}{1.} & \multirow{2}{*}{ Ampenan } & 1. Bakso 1 & & & & \\
\hline & & 2. Bakso 2 & & & & \\
\hline \multirow[b]{2}{*}{2.} & \multirow[b]{2}{*}{ Cakranegara } & 3. Bakso 3 & & & & \\
\hline & & 4. Bakso 4 & & & & \\
\hline \multirow[b]{2}{*}{3.} & \multirow{2}{*}{ Mataram } & 5. Bakso 5 & & & & \\
\hline & & 6. Bakso 6 & & & & \\
\hline & & 7. Bakso 7 & & & & \\
\hline 4. & Sekarbela & 8. Bakso 8 & & & & \\
\hline 5. & & 9. Bakso 9 & & & & \\
\hline 5. & Sandubaya & 10. Bakso 10 & & & & \\
\hline & & 11. Bakso 11 & & & & \\
\hline 6. & Selaparang & 12. Bakso 12 & & & & \\
\hline
\end{tabular}

\section{HASIL DAN PEMBAHASAN}

\section{Hasil Penelitian}

a. Keberadaan Boraks dan Formalin

Data hasil penelitian dan hasil analisis uji kandungan boraks dan formalin pada bakso di pedagang bakso di Wilayah Kota Mataram dapat dilihat pada Tabel 3.

Tabel 3 .

Hasil Uji Keberadaan Boraks Dan Formalin Terhadap Sampel Bakso di Wilayah Kota Mataram.

\begin{tabular}{|c|c|r|}
\hline Perlakuan & Boraks (1) & Formalin (2) \\
\hline B.1 & - & + \\
\hline B. 2 & - & + \\
\hline B.3 & - & + \\
\hline B.4 & - & + \\
\hline B.5 & - & + \\
\hline B.6 & - & + \\
\hline B.7 & - & + \\
\hline B.8 & - & + \\
\hline B.9 & - & + \\
\hline B.10 & - & + \\
\hline B.11 & - & + \\
\hline B.12 & - & $100 \%$ \\
\hline Jumlah & 0\% (Negatif) & \\
Keterangan: $-=$ Negatif & Positif &
\end{tabular}

Pada Tabel 3 kolom 1 menunjukkan bahwa hasil analisis keberadaan boraks pada bakso diwilayah kota mataram 0\% (negatif) tidak ada mengandung boraks. yaitu pedagang dengan kode $\mathrm{B} 1$, B2, B3. B4 B5, B6, B7, B8, B9 B.10, B11, B12. (100\% tidak ada yang menggunakan boraks).

Pada Tabel 3 kolom 2 menunjukkan bahwa 100\% pedagang bakso di wilayah kota mataram positif mengandung formalin. yaitu pedagang dengan kode 
B1, B2, B3. B4 B5, B6, B7, B8, B9 B10, B11, B12. (100\% menggunakan formalin dalam pembuatan baksonya).

b. Kadar Air Bakso

Signifikansi pengaruh keberadaan boraks dan formalin terhadap kadar air bakso pada beberapa pedagang di kota mataram dapat dilihat pada Tabel 4.

Tabel 4.

Signifikansi pengaruh keberadaan boraks dan formalin terhadap kadar air bakso yang ada diwilayah kota mataram

\begin{tabular}{|l|l|l|l|}
\hline Parameter & F Hitung & F Tabel & Keterangan \\
\hline Kadar Air & 1.4959 & 2.22 & NS \\
\hline
\end{tabular}

Keterangan: NS= Non Signifikan (Tidak Berpengaruh Nyata)

Pada Tabel 4. Menunjukkan bahwa keberadaan boraks dan formalin pada bakso tidak berpengaruh nyata terhadap sifat kimia kadar air bakso, sehingga tidak dilakukan uji lanjut dengan uji lanjut Beda Nyata J ujur (BNJ ) pada taraf nyata 5\%. Hasil purata kadar air dapat dilihat pada Tabel 5.

\begin{tabular}{|c|c|}
\hline Perlakuan & Kadar Air ( \%) \\
\hline B1 & 76.778 \\
\hline B2 & 71.976 \\
\hline B3 & 65.592 \\
\hline B4 & 71.392 \\
\hline B5 & 73.760 \\
\hline B6 & 77.647 \\
\hline B7 & 71.563 \\
\hline B8 & 75.040 \\
\hline B9 & 70.483 \\
\hline B10 & 69.637 \\
\hline B11 & 73.276 \\
\hline B12 & 70.932 \\
\hline
\end{tabular}

Tabel 5. Menunjukkan hasil analisis signifikansi terhadap kadar air bakso tidak berbeda nyata antar perlakuan yang diamati dengan kadar air berkisar antara (65.592\% sampai 77. 647\%).

c. Sifat Organoleptik Bakso

Hasil Pengamatan keberadaan boraks dan formalin terhadap sifat organoleptik bakso pada pedagang bakso di kota mataram dapat dilihat pada tabel 6.

Tabel 6.

Signifikasi keberadaan boraks dan formalin terhadap sifat organoleptik warna, aroma, tekstur, rasa pada pedagang bakso diwilayah kota mataram.

\begin{tabular}{|l|l|l|c|}
\hline Parameter & F hitung & F tabel & Signifikasi \\
\hline Warna & 5,020 & 1.73 & S \\
Aroma & 1,078 & 1.73 & NS \\
Tekstur & 3,159 & 1.73 & S \\
Rasa & 0,964 & 1.73 & NS \\
\hline
\end{tabular}

Pada Tabel 6 menunjukkan bahwa keberadaan boraks dan formalin pada pedagang bakso di wilayah kota mataram berpengaruh nyata terhadap skor nilai warna dan tekstur, sehingga dilakukan uji lanjut dengan uji Beda Nyata J ujur (BNJ) pada taraf nyata $5 \%$. Sedangkan untuk skor nilai aroma dan rasa tidak berpengaruh secara nyata. Sehingga tidak dilakukan uji lanjut dengan uji Beda Nyata Jujur (BNJ) pada taraf nyata 5\%. Purata hasil analisa sifat organoleptik uji Beda Nyata J ujur (BNJ) pada taraf 5\% dapat dilihat pada Tabel 7.

Tabel 7.

Purata hasil analisa sifat organoleptik warna, aroma, tekstur, dan rasa pada bakso diwilayah kota mataram.

\begin{tabular}{|l|l|l|l|l|}
\hline Perlakuan & Warna & Aroma & Tekstur & Rasa \\
\hline B.1 & $1.93 \mathrm{a}$ & 3.40 & $2.07 \mathrm{a}$ & 3.67 \\
\hline B.2 & $1.87 \mathrm{a}$ & 2.93 & $2.00 \mathrm{a}$ & 3.20 \\
\hline B.3 & $3.67 \mathrm{~b}$ & 3.00 & $2.47 \mathrm{ab}$ & 3.67 \\
\hline B.4 & $2.60 \mathrm{ab}$ & 3.13 & $2.40 \mathrm{ab}$ & 3.47 \\
\hline B.5 & $1.93 \mathrm{a}$ & 2.93 & $2.87 \mathrm{ab}$ & 3.40 \\
\hline B.6 & $3.33 \mathrm{~b}$ & 2.80 & $2.60 \mathrm{ab}$ & 2.93 \\
\hline B.7 & $2.67 \mathrm{ab}$ & 2.67 & $2.07 \mathrm{a}$ & 3.07 \\
\hline B.8 & $2.87 \mathrm{ab}$ & 3.33 & $2.27 \mathrm{a}$ & 3.60 \\
\hline B.9 & $3.07 \mathrm{ab}$ & 3.27 & $3.00 \mathrm{ab}$ & 3.53 \\
\hline B.10 & $2.87 \mathrm{ab}$ & 3.27 & $2.67 \mathrm{ab}$ & 3.40 \\
\hline B.11 & $3.60 \mathrm{~b}$ & 3.53 & $3.47 \mathrm{~b}$ & 3.33 \\
\hline B.12 & $3.13 \mathrm{ab}$ & 3.07 & $2.53 \mathrm{ab}$ & 3.00 \\
\hline Nilai BNJ & 1.308 & - & 1.135 & - \\
\hline
\end{tabular}

Pada Tabel 7 kolom pertama (Warna) menunjukkan bahwa pada perlakuan B1 tidak berbeda nyata dengan B2, B4, B5, B7, B8, B9, B10, dan B12 tapi berbeda nyata dengan B3, B6, dan B11. Perlakuan B2 tidak berbeda nyata dengan B1, B4, B5, B7, B8, B9, B10, dan B12 tapi berbeda nyata dengan perlakuan B3, B6, Dan B11. Perlakuan B3 tidak berbeda nyata dengan B6, dan B11 tapi berbeda nyata dengan perlakuan B1, B2, B4, B5, B7, B8, B9, B10 dan B12. Perlakuan B4, tidak berbeda nyata dengan B1, B2, B5, B7, B8, B9, B10,dan B12, tapi berbeda nyata dengan perlakuan B3, B6, dan B11. Perlakuan B5, tidak berbeda nyata dengan B1, B2, B4, B7, B8, B9, B10, dan B12. Tapi berbeda nyata dengan perlakuan B3, B6, dan B11. Perlakuan B6 tidak berbeda nyata dengan B3, dan B11 tapi berbeda nyata dengan perlakuan B1, B2, B4, B5, B7, B8, B9, B10 dan B12. Perlakuan B7, tidak berbeda nyata dengan B1, B2, B4, B5, B8, B9, B10, dan B12, Tapi berbeda nyata dengan perlakuan B3, B6, dan B11. Perlakuan B8, tidak berbeda nyata dengan B1, B2, B4, B5, B7, B9, B10, dan B12 Tapi berbeda nyata dengan perlakuan B3, B6, dan B11. Perlakuan B9, tidak berbeda nyata dengan B1, B2, B4, B5, B7, B8, B10, dan B12. Tapi berbeda nyata dengan perlakuan B3, B6, dan B11. Perlakuan B10, tidak berbeda nyata dengan B1, B2, B4, B5, B7, B8, B9, dan B12. Tapi berbeda nyata dengan perlakuan $\mathrm{B} 3, \mathrm{~B} 6$, dan $\mathrm{B} 11$. Perlakuan B11 tidak berbeda nyata dengan B3, dan B6 tapi berbeda nyata dengan perlakuan B1, B2, B4, B5, B7, B8, B9, B10 dan B12. Perlakuan B12, tidak 
berbeda nyata dengan B1, B2, B4, B5, B7, B8, B9, dan B10. Tapi berbeda nyata dengan perlakuan B3, B6, dan B11.

Pada Tabel 7. Kolom kedua (aroma) menunjukkan pada semua perlakuan pada uji organoleptik aroma tidak berbeda nyata dengan semua perlakuan atau non signifikan sehingga tidak dilakukan uji lanjut dengan BNJ taraf 5\%.

Pada Tabel 7 kolom ketiga ( Tekstur ) menunjukkan bahwa pada perlakuan B1 tidak berbeda nyata dengan B2, B3, B4, B5, B6, B7, B8, B9, B10, dan B12 tapi berbeda nyata dengan B11. Perlakuan B2 tidak berbeda nyata dengan B1, B3, B4, B5, B6, B7, B8, B9, B10, dan B12 tapi berbeda nyata dengan B11. Perlakuan B3 tidak berbeda nyata dengan B1, B2, B4, B5, B6, B7, B8, B9, B10, dan B12 tapi berbeda nyata dengan B11. Perlakuan B4 tidak berbeda nyata dengan B1, B2, B3, B5, B6, B7, B8, B9, B10, dan B12 tapi berbeda nyata dengan B11. Perlakuan B5 tidak berbeda nyata dengan B1, B2, B3, B4, B6, B7, B8, B9, B10, dan B12 tapi berbeda nyata dengan B11. Perlakuan B6 tidak berbeda nyata dengan B1, B2, B3, B4, B5, B7, B8, B9, B10, dan B12 tapi berbeda nyata dengan B11. Perlakuan B7 tidak berbeda nyata dengan B1, B2, B3, B4, B5, B6, B8, B9, B10, dan B12 tapi berbeda nyata dengan B11. Perlakuan B8 tidak berbeda nyata dengan B1, B2, B3, B4, B5, B6, B7, B9, B10, dan B12 tapi berbeda nyata dengan B11. Perlakuan B9 tidak berbeda nyata dengan B1, B2, B3, B4, B5, B6, B7, B8, B10, dan B12 tapi berbeda nyata dengan B11. Perlakuan B10 tidak berbeda nyata dengan B1, B2, B3, B4, B5, B6, B7, B8, B9, dan B12 tapi berbeda nyata dengan B11. Perlakuan B11 berbeda nyata dengan semua perlakuan B1, B2, B3, B4, B5, B6, B7, B8, B9, B10 dan B12. Perlakuan B12 tidak berbeda nyata dengan B1, B2, B3, B4, B5, B6, B7, B8, B9, dan B10 tapi berbeda nyata dengan B11.

Pada Tabel 7. Kolom keempat (rasa) menunjukkan semua perlakuan pada uji organoleptik rasa tidak berbeda nyata antar perlakuan (non signifikan) sehingga tidak dilakukan uji lanjut.

\section{Pembahasan}

Berdasarkan hasil penelitian dan analisis data yang terbatas pada ruang lingkup penelitian ini maka dapat dikemukakan pendapat sebagai berikut:

1. Uji Kandungan Boraks Dan Formalin

a. Boraks

Grafik keberadaan boraks pada bakso yang dijual diwilayah kota mataram dapat dilihat pada Gambar 1.

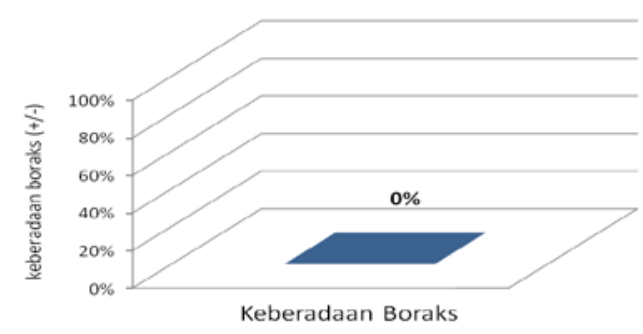

Gambar 1.Grafik keberadaan boraks pada bakso yang di penjual di wilayah kota mataram.

Berdasarkan Gambar 1, menunjukkan bahwa tidak satupun pedagang bakso yang berjualan di wilayah kota mataram yang baksonya mengandung boraks yang dapat membahayakan kesehatan manusia. Identifikasi penambahan boraks pada bakso di wilayah kota mataram menunjukkan bahwa tidak ada yang mengandung boraks disetiap sampel yang diteliti. Hal ini disebabkan karena para pedagang bakso diwilayah kota mataram sudah menyadari akan bahaya dari efek kandungan boraks yang berdampak bagi kesehatan manusia, Bila boraks terkonsumsi oleh manusia dengan kadar tinggi akan dapat menyebabkan gangguan proses reproduksi menimbulkan iritasi pada lambung, dan atau menyebabkan gangguan pada ginjal, hati, dan testes (Suklan 2002).

Sering mengkonsumsi makanan berboraks akan menyebabkan gangguan otak, hati, lemak dan ginjal. Dalam jumlah banyak, boraks menyebabkan demam, anuria (tidak terbentuknya urin), koma, merangsang sistem saraf pusat, menimbulkan depresi, apatis, sianosis, tekanan darah turun, kerusakan ginjal, pingsan bahkan kematian (Widyaningsih dan Murtini, 2006).

b. Formalin

Grafik keberadaan formalin pada bakso yang di dijual diwilayah kota Mataram dapat dilihat pada Gambar 2.

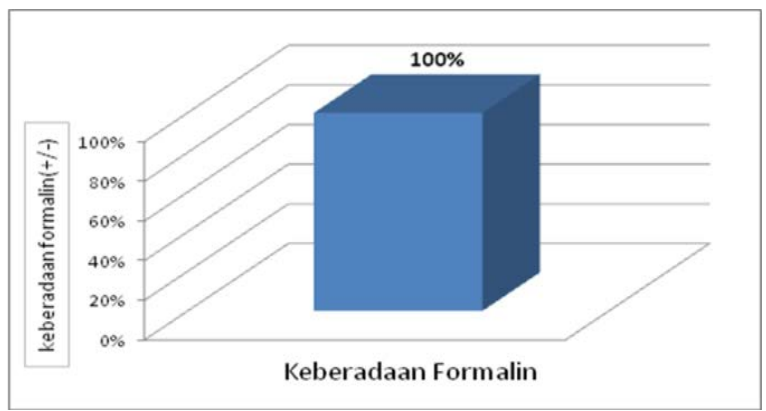

Gambar 2. Grafik keberadaan formalin pada bakso di penjual bakso di wilayah kota mataram.

Pada Gambar 2. Dapat dilihat bahwa penggunaan formalin pada bakso sangat tinggi untuk pengawetan bakso yaitu $100 \%$ dari total sampel yang diteliti. Setelah dilakukan dua kali pengujian pada saat penelitian untuk memastikan bahwa pada bakso tersebut apakah benar- benar positif atau negatif 
mengandung formalin dan ternyata setelah diteliti $100 \%$ positif mengandung formalin. Hal ini Sangat menghawatirkan dikarenakan larutan formalin yang digunakan untuk pembunuh kuman, pembersih lantai dan pengeras kuku, digunakan untuk mengawetkan bakso tidak terbayangkan apabila formalin terkonsumsi oleh masyarakat (Harmita, 2010).

Menurut Teddy (2007). Formalin digunakan sebagai bahan pengawet makanan yang mengandung kadar air tinggi. Produk atau makanan yang mengandung kadar air tinggi sangat disukai oleh mikroba sehingga masa simpannya tidak akan lama akibat pertumbuhan mikroba pada makanan tersebut. Sehingga pada proses pembuatan bakso penambahan zat pengawet yaitu formalin sengaja digunakan pada produk olahan bakso, agar masa simpan dari produk bakso tersebut menjadi tahan lama.

Berdasarkan hasil uji laboratorium dengan menggunakan teskit satu jenis dapat dikatakan bahwa bakso yang diproduksi beberapa pedagang bakso di kota mataram belum tergolong halal. Makanan halal akan mencakup hal yang jelas pelarangannya melalui nash-nash agama, misalnya islam melarang makan babi, darah atau sembelihan yang tidak menyebut nama Allah, juga berkaitan dengan eksistensi kesehatan manusia. Dari poin diatas menunjukkan persoalan produk halal tidak saja berkaitan dengan kebutuhan mengikuti syariah tapi juga berkaitan dengan higienitas, sanitasi dan juga keamanan ( Baharuddin, et al, 2015 ).

2. Uji Sifat Kimia

a. Kadar Air

Perlakuan keberadaan boraks dan formalin tidak berpengaruh nyata terhadap kadar air bakso dapat dilihat pada (Tabel 5). Grafik hubungan keberadaan formalin terhadap kadar air pada bakso dapat dilihat pada Gambar 3.

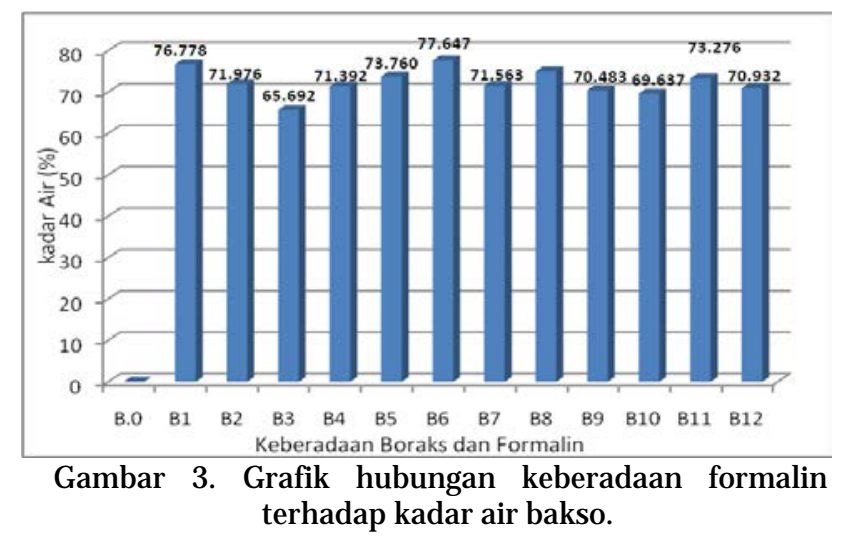

Gambar 3. Menunjukkan bahwa kadar air tertinggi diperoleh pada perlakuan B6 yaitu sebesar 77.647\%. Sedangkan kadar air terendah diperoleh pada perlakuan B3 yaitu sebesar $65.692 \%$. Namun secara matematis tidak menunjukkan beda nyata antara perlakuan, hal ini menunjukkan bahwa keberadaan formalin pada bakso tidak mempengaruhi sifat kadar air bakso. J ika dibandingkan dengan kadar air bakso menurut standar SNI yaitu 70,0\%. Dalam hal ini sampel yang melewati standar kadar air bakso SNI tersebut mungkin dipengaruhi oleh senyawa kimia, suhu, konsistensi, dan interaksi dengan komponen penyusun makanan seperti protein, lemak, asam-asam lemak bebas, dan komponen lainnya (Winarno. 2002).

\section{Uji Organoleptik}

a. Warna

Perlakuan pengaruh keberadaan boraks dan formalin bakso berpengaruh nyata terhadap skor nilai warna bakso (Tabel 6 kolom 1). Grafik hubungan pengaruh keberadaan boraks dan formalin terhadap skor nilai warna bakso dapat dilihat pada Gambar 4 .

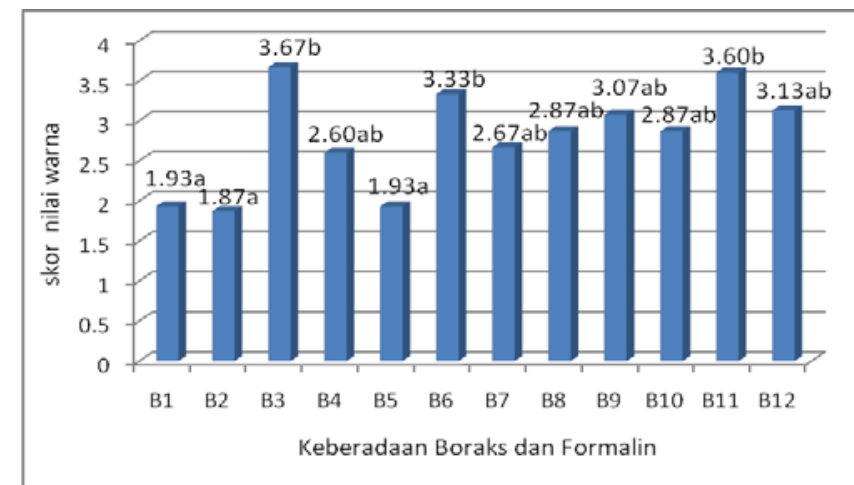

Gambar 4. Grafik Pengaruh Keberadaan Formalin Terhadap Warna Bakso.

Gambar 4. menunjukkan bahwa skor nilai warna memiliki pengaruh yang nyata terhadap bakso. Hasil penilaian panelis terhadap skor nilai warna bakso menghasilkan skor nilai warna 1.87 (Agak putih) sampai dengan 3.67 (agak coklat). Pada perlakuan B1, B2, B5, memiliki warna (Agak putih). Pada perlakuan B4, B6, B7, B8, B9, B10 dan B12 memiliki warna (abuabu). Sedangkan pada perlakuan B3 dan B11 memiliki warna (coklat). Pada Gambar 4. Menunjukkan respon 15 orang panelis terhadap warna bakso, Dalam hal ini sampel dengan skor nilai warna terendah pada perlakuan B2 yaitu 1.87 dengan penggunaan formalin pada bakso tersebut sangat tinggi, sedangkan skor nilai warna tertinggi pada perlakuan B3 yaitu 3.67 dengan penggunaan formalin agak sedikit, sehingga dapat diketahui bahwa keberadaan formalin pada pedagang bakso diwilayah kota Mataram berpengaruh terhadap warna bakso.

Warna suatu bahan pangan mempunyai peranan penting dalam penetuan mutu. Warna produk bakso yang menggunakan formalin berwarna putih sedangkan warna produk bakso yang aman mengandung formalin berwarna abu-abu segar merata disemua bagian. Warna produk bakso diantara dipengaruhi oleh beberapa aspek diantaranya penambahan formalin dan juga kandungan miglobin semakin tinggi miglobin daging 
maka warna daging semakin merah. Warna merah pada daging akan mengalami perubahan menjadi warna abu-abu kecoklatan selama pemasakan karena terjadinya proses oksidasi (soeparno 2005).

b. Aroma

Perlakuan pengaruh keberadaan boraks dan formalin pada bakso tidak berpengaruh secara nyata terhadap nilai aroma bakso dapat dilihat pada (Tabel 6 kolom 2). Grafik hubungan pengaruh keberadaan boraks dan formalin terhadap aroma bakso dapat dilihat pada Gambar 5.

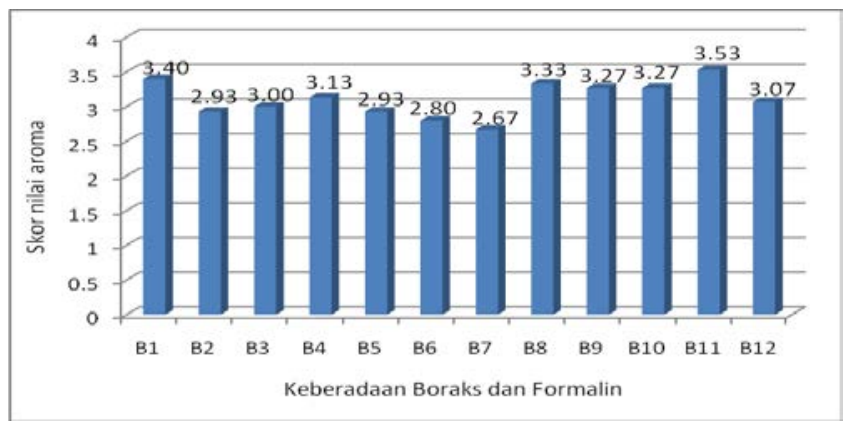

Gambar 5. Grafik hubungan keberadaan formalin terhadap skor nilai aroma bakso.

Gambar 5 Menunjukkan bahwa skor nilai aroma bakso tidak berpengaruh nyata terhadap aroma bakso. Hasil penilaian terhadap aroma bakso menghasilkan tingkat kesukan panelis dengan skor nilai 2.67 (agak suka) sampai 3.53 (suka). Pada perlakuan B1, B2, B3, B4, B5, B6, B7, B8, B9, B10 dan B12 memiliki aroma yang cenderung agak disukai oleh panelis. Sedangkan perlakuan B11 memiliki aroma yang cenderung disukai oleh panelis. Dalam hal ini pengaruh keberadaan formalin pada bakso tidak memberikan pengaruh nyata terhadap parameter aroma bakso.

Aroma suatu produk daging olahan dapat dipengaruhi oleh jenis, lama dan suhu pemasakan, selain itu aroma produk olahan dapat juga dipengaruhi oleh bahan yang ditambahkan selama pembuatan dan pemasakan terutama bumbunya (Winarno, 1997).

\section{c. Tekstur}

Perlakuan pengaruh hubungan keberadaan boraks dan formalin terhadap skor nilai bakso berbeda nyata terhadap nilai tekstur dapat dilihat pada pada (Tabel 6 kolom 3). Grafik pengaruh hubungan keberadaan boraks dan formalin pada tekstur bakso dapat dilihat pada Gambar 6.

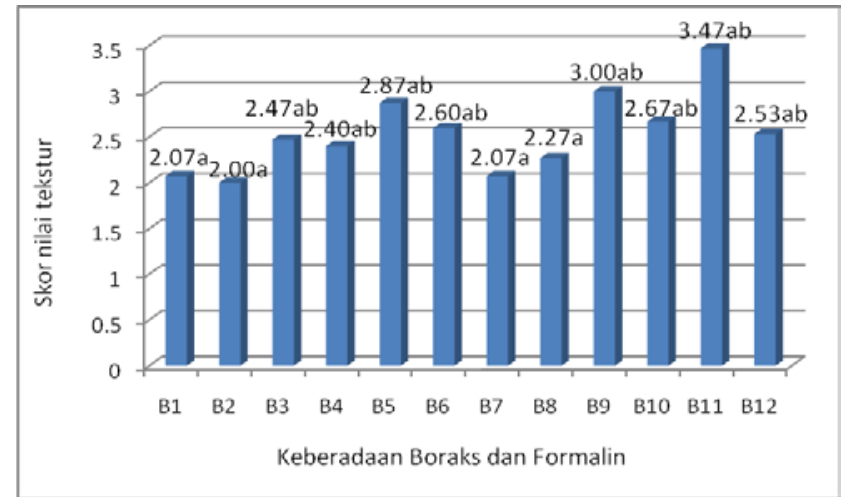

Gambar 6. Grafik pengaruh hubungan keberadaan formalin pada tekstur bakso

Gambar 6 menunjukkan Skor nilai tekstur memiliki pengaruh nyata terhadap bakso. Hasil penilaian skor tekstur tertinggi diperoleh pada perlakuan B11 sebesar 3.47. dengan kriteria (Kenyal) dan skor nilai terendah diperoleh pada perlakuan B2 yaitu sebesar 2.00 dengan kriteria (agak keras). Pada perlakuan B5, B6, B9, B10, B11, dan B12 memiliki tekstur (kenyal), Sedangkan perlakuan B1, B2, B3, B4, B7, B8, memiliki tekstur yang (agak keras). panelis lebih menyukai tekstur bakso yang kenyal karena memiliki tekstur yang selera dengan panelis yang mana tekstur-tekstur bakso tersebut lebih disukai dan menimbulkan sensasi yang lebih baik ketika digigit dan dikunyah. Pada Gambar 6 . Menunjukkan respon 15 orang panelis terhadap tekstur bakso. Dalam hal ini sampel dengan skor nilai tekstur terendah pada perlakuan B2 yaitu 2.00 dengan penggunaan formalin sangat tinggi, sedangkan skor nilai tekstur tertinggi pada perlakuan B11 yaitu 3.47 dengan penggunaan formalin agak sedikit. Sehingga dapat diketahui bahwa keberadaan formalin pada pedagang bakso diwilayah kota mataram berpengaruh terhadap tekstur bakso.

Menurut Widyaningsih dan Murtini (2006), bakso yang menggunakan bahan pengawet formalin mempunyai tingkat tekstur yang lebih keras dibandingkan pada bakso pada umumnya.

d. Rasa

Perlakuan pengaruh hubungan keberadaan boraks dan formalin terhadap bakso tidak berpengaruh nyata terhadap skor nilai rasa bakso (Tabel 6 kolom 4). Grafik hubungan keberadaan boraks dan formalin terhadap bakso dapat dilihat pada Gambar 7.

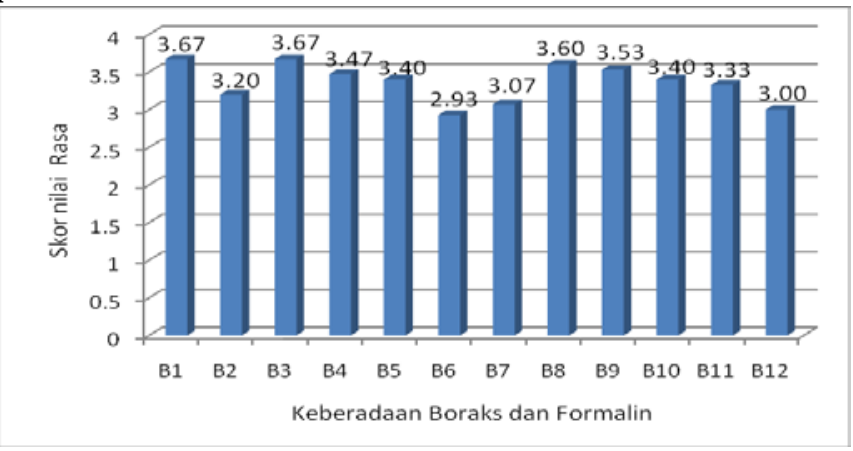

Gambar 7. Grafik hubungan keberadaan boraks dan formalin terhadap rasa bakso. 
Gambar 7 menunjukkan bahwa skor nilai rasa tidak berpengaruh secara nyata terhadap rasa bakso. Hasil penilaian panelis terhadap rasa bakso menghasilkan tingkat kesukaan antara 2.93 (agak suka) sampai 3.67 (suka). Hasil uji organoleptik terhadap rasa menunjukkan bahwa perlakuan B1, B3, B8, dan B9 memiliki rasa yang disukai panelis. Sedangkan untuk perlakuan B2, B4, B5, B6, B7, B10, B11 dan B12 memiliki rasa yang agak disukai panelis. Dalam hal ini pengaruh keberadaan formalin pada bakso tidak memberikan pengaruh nyata terhadap parameter rasa bakso.

Rasa suatu produk pangan dapat dipengaruhi oleh beberapa faktor diantaranya senyawa kimia, temperatur, konsistensi, dan interaksi dengan komponen rasa yang lain serta jenis dan lama pemasakan (Winarno, 1997).

\section{SIMPULAN DAN SARAN}

\section{A. Simpulan}

Berdasarkan hasil penelitian dan pembahasan dapat disimpulkan hal-hal sebagai berikut:

a. Hasil uji keberadaan kandungan boraks menunjukkan bahwa (0\% negatif) pedagang bakso diwilayah kota Mataram tidak menggunakan boraks pada bakso yang dijual. Sedangkan uji keberadaan kandungan formalin pada bakso dibeberapa pedagang bakso diwilayah kota Mataram menunjukkan $100 \%$ menggunakan bahan formalin.

b. Hasil uji sifat kimia parameter kadar air menunjukkan bahwa keberadaan boraks dan formalin tidak berpengaruh secara nyata terhadap kadar air bakso.

c. Hasil uji sifat organoleptik menunjukkan bahwa kandungan boraks dan formalin berpengaruh secara nyata terhadap parameter warna dan tekstur namun tidak berpengaruh secara nyata terhadap pada parameter aroma dan rasa.

d. Dari sifat organoleptik (warna, aroma, tekstur, dan rasa) panelis menyukai semua perlakuan yang di uji.

e. Berdasarkan hasil analisis sebagian besar pedagang bakso di Kota Mataram belum termasuk Halalan Thoyiban karena menggunakan formalin dalam proses produksi bakso.

\section{B. Saran}

Berdasarkan hasil penelitian yang dilakukan maka dapat dikemukakan saran-saran sebagai berikut:

a. Untuk mengkonsumsi bakso yang tidak mengandung bahan pengawet yang berbahaya disarankan kepada masyarakat untuk lebih selektif dalam memilih pedagang bakso.

b. Untuk penelitian lebih lanjut sebaiknya melakukan beberapa uji lanjutan untuk memastikan keberadaan bahan tambahan makanan yang berbahaya pada produk bakso yang diteliti.

c. Untuk penelitian selanjutnya perlu dilakukan penelitian mengenai lama simpan bakso yang mengandung boraks dan formalin.

\section{DAFTAR RUJ UKAN}

[1] Aminah dan Himawan. 2009. Bahan-Bahan Berbahaya dalam Kehidupan.Bandung: Salamadani.

[2] Apriyanti (2007). Analisis kandungan formalin yang dijual di kios bakso permanen dibeberapa tempat di kota bitung jurnal kesehatan. Manado: fakultas kesehatan masyarakat UNSRAT.

[3] Astawan M. 2004. Kandungan Gizi Aneka Makanan. Gramedia. Jakarta.

[4] Budiarto, 2004. Metodologi Penelitian Kedokteran Sebuah Pengantar.J akarta: EGC

[5] Cahyadi, W. 2008. Analisis dan Aspek Kesehatan Bahan Tambahan Pangan Edisi 2 Cetakan I. J akarta: Bumi Aksara

[6] Depkes R.I. 2001. Pedoman Program Perbaikan Gizi di Indonesia. Jakarta

[7] Depkes R.I. 2002. Pedoman Penggunaan Bahan Tambahan Pangan bagi Industri.J akarta

[8] ET. Group. 2018. Tes Kit Boraks Dan Formalin.

[9] Fardiaz, S. 2007. Bahan Tambahan Makanan. Institut Pertanian Bogor. Bandung

[10] Fitri A.L. 2014. Analisis Kandungan Formalin Dan Boraks Pada Bakso Yang Disajikan Kios Bakso Permanen Pada Beberapa Tempat Di Kota Bitung. Sulawesi utara. Fakultas Kesehatan Masyarakat Universitas Sam Ratulangi.

[11] Hanafiah. 2001. Mikroorganisme Pelarut P Sebagai Alternatif Pengganti Fungsi Pupuk TSP dan Kapur Dalam Mengatasi Ketersediaan Fospat Bagi Tanaman. Makalah Dibawakan Pada Seminar Hasil-hasil Pertanian RATAXV.BKS-BTN Barat Bandar Lampung.

[12] Harmita, APT. 2010. Analisa Fisikokimia. UI Press. Jakarta

[13] Handinsyah dan Sumali, 2001. Pengendalian Mutu dan Keamanan Pangan. Jakarta

[14] Koswara, S. 2009. Teknologi Pengolahan Mie. eBookPangan.com.

[15] Legowo, A. M; Nurwantoro dan Sutaryo , 2005. Analisis Pangan. Penerbit Universitas Diponogoro, Semarang.

[16] Malangi,L.P. 2012. penentuan kandungan tanin dan uji aktifits antioksidan Ekstrak biji buah Alpukat (persea americana mill) J URNAL MIPA UNSRAT vol. 1(1) : 510

[17] Mahpolah. S.N, 2015. Penelitian Bahan Berbahaya Formalin, Boraks, Rhodamin B dan Methalyn Yellow Pada Pangan J ajanan Anak Sekolah di Banjar Baru.

[18] Munir, Badrul. 2016. Menjadikan NTB Pusat Pangan Halal Dunia. Suara NTB, 29 Februari 2016

[19] Riandini 2008, Bahan Makanan Dalam Makanan dan Minuman. Bandung: Shakti Adiluhung.

[20] Rohman, A. dan Sumantri. 2007. Analisis Makanan. Institut Teknologi Bandung. Bandung.

[21] Rustandi,D. 2011. Powerful UKM: ProduksiMie. PT Tiga Serangkai Pustaka Mandiri. Solo. $124 \mathrm{Hal}$.

[22] Saparinto, C. Hidayati, D. 2006. Bahan Tambahan Pangan. Yogyakarta: Kanisius

[23] Svehla G, 2012. Kandungan Boraks pada Bakso di Makasar. Jurnal Kesehatan Makasar: Program studi kedokteran hewan Fakultas Kedokteran Universitas Hasanudin Makasar.

[24] Seto, S. 2001 Pangan dan Gizi Ilmu Teknologi Industri dan Perdagangan Internasional. Bogor: Fakultas Teknologi Pertanian

[25] Setyaningsih, Dwi, Apriyantono, Anton, dan sari, 2010 cara uji hedonic Universitas Pendidikan Indonesia Repository. Upi. Edu perpustakaan.upi.edu 
[26] Singgih 2009, Karakteristik Mutu Bakso Daging Sapi Dan Pengaruh Penambahan $\mathrm{NaCl}$ dan Natrium Tripolyposfat terhadap perbaikan mutu. Disertai program Pasca Sarjana. Institut Pertanian Bogor.

[27] Suklan H., Apa dan Mengapa Boraks Dalam Makanan. Penyehatan Air dan Sanitasi (PAS). 2002; Vol. IV Nomor 7

[28] Syah, D., 2005. Manfaat dan Bahaya Bahan Tambahan Pangan. Bogor: Himpunan Alumni Fakultas Teknologi Pertanian IPB

[29] Soekarto. 1990. Dasar-dasar Pengawasan dan Standarisasi Mutu Pangan. Bogor.

[30] Dirjen Pusat Antar Uiversitas Pangan dan Gizi Institut Pertanian Bogor.

[31] Soeparno, 2005. Ilmu dan teknologi daging. Gadjah Mada, University press Yogyakarta.

[32] Teddy. 2007. Pengaruh Konsentrasi Formalin Terhadap Keawetan Bakso dan Cara Pengolahan Bakso terhadap residu formalinnya. Skripsi Fakultas Teknologi Pertanian IPB. Bogor.

[33] Purnomo 1998, Membuat Bakso Daging Dan Dagig ikan. Kanisius Yogyakarta. Purnawijayanti, H.A. 2009 Mie Sehat. Yogyakarta : Kanisius

[34] Widyaningsih, T.D. dan Murtini, ES. 2006. Alternatif Pengganti Formalin Pada Produk Pangan. Jakarta: Trubus Agrisarana

[35] Yuliarti, N. 2007. Awas Bahaya Di Balik Lezatnya Makanan. Yogyakarta

[36] Wibowo, S. 2010. Pembuatan Bakso Ikan dan Bakso Daging. J akarta, penebar Swadaya.

[37] Winarno. FG. 1997. Kimia Pangan dan Gizi. PT Gramedia Pustakan Utama, Jakarta. 